\author{
（触覚センサーを用いた食肉の識別）
}

\author{
准 $\bigcirc$ 松田光央 (日大院) 正坂野進（日大工）
}

\title{
A Basic Research for Discrimination of Living Body Tissues \\ (Discrimination of Meats using Tactile Sensor)
}

\author{
Mitsuo Matsuda, Susumu Sakano \\ "Dept. of Mechanical Engineering, College of Engineering, Nihon University \\ 1 Nalkiggawara, Tolisusada, Tamura-cho, Koriyama-shi, Fulkushima, $963-8642$
}

\begin{abstract}
The palpations ane used for the diagnosis of liver cirnhosis, peritonitis, mammary cancer, thyroid cancer, etc., in the medical instrituions. In the operations, the doctors carry out the treatment by palpating the organs of the patient The trials for automatically operation ane carried out using robot and image sensor. It is dispensable to develop the discriminating method of the human body tissues for the automation of the operation using robots. The piezoelectric elements are used as the sensor to measure the qualities of the living body. The discrimination for various meats as the living body is tried using the developed tactile sensor. It is shown that the discrimination among the living tisstes is possible using the tactile sensor.
\end{abstract}

Key Words: Tadile Sensor. PiezoeledricElement. Human Body Tissue. EudidDistance. Disximination of Body Tissues

1. 緒言

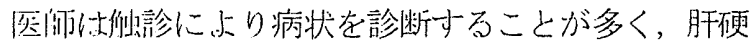
変，腹膜炎，乳ぶん，などのいろいろの病状の診断

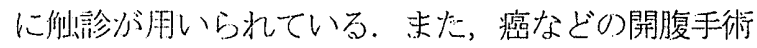
において怗医師が直接に臟器に触れることによって 治潦を行っている。このように触診から得られる情 郝仗㭧者の患部の位置や状況を見極める上で非常に 重要なものとなっている。本研究では，生体組織の 棓洌它目的として圧電素子を基本とした触覚センサ 一扎よびセンシングシステムを構成した，触覚セン

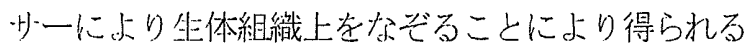

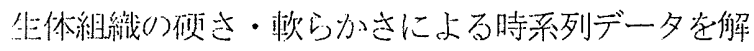
悄ひ基とした。得られた時系列データを最大エント 口ビ泣・MEM(Maximum Entropy Method)により周波 数久ベクトル化する。 さらに，EED法（Evaluation by Euclid Distanœ）法を用いて解析寸ることにより生 休組䋐の識别を試みる。本研究では，生体組織とし て各程の食肉炎用いた。食肉の種類と肉の部位の識 别妾制为\%。
2. センサーおよびセンシングシステム

ジルコンチタン酸鉛（PZT）の圧電素子を市販の ボールベン軸に組み込むことにより触覚センサーを 構成した。圷電素子を用いた予備実験で，一定の上 下位置で食肉の表面をな无るために㤌人が筆記する 要領で行えばよく，また，文字「2」を描くように して食肉の表面をなぞれ就繰り返しの誤差の少ない 圧力を得られることが解った，そこで，触覚センサ 一の構成にはボールペンを用いた，図1にセンサー の構成と压力のセンシングの方法を示す，一個の円 筒状の PZT がボールペン軸に固定され，ボールペ ン軸を共振するるため使われる。 もう一個の円筒状 の PZT 名云の外側に設けられ，振動の検出に使わ れる。共振状態にあったボールペン軸が何か心測定 刘象物に接触すると共振振動数は变化与一。. 測定刘 象物の音響負荷の違いにより共振振動数ぶ变化ずる ことを利用する。，生体組織の表面を触覚センサー午で なぞった時に得られる共振振動数の变化を時系列デ 一タとして用いる. 


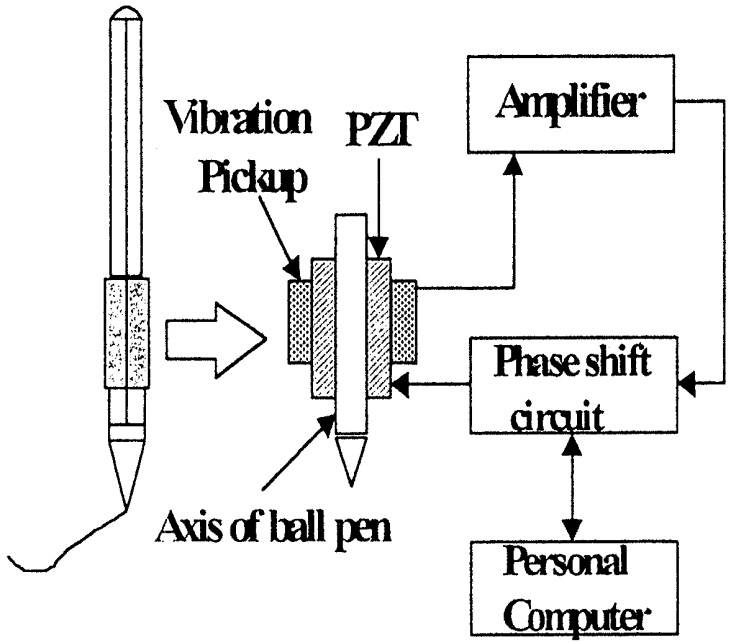

Fig. 1 Structure of bell-pointpen and measuring circuit;

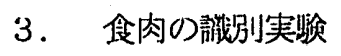

3. 1 实険方法 圧霆素子を組み込んだボール ペンを朋いて食肉の裴面に「2」の字を描くようにし てな无った「2」の字を描くようにしてなぞるのは ボールベンの籰圧をほぼー定にでき，肉の硬さの検出 が实定して得られるからである。いろいろの文字を描 いて定定性艾確認し，「2」の文字とした，食肉の表 面をなぞることにより得られる時系列データを用いて 識別実験学行った，用いた食肉とその部位を表 1 に示 寸。識别実験手順は以下のとおりである。

（1）基準と小石食肉部位（も当肉）の表面に「2」

企10回描き，殴雪素子かから得られる時系列データを 収集可学。

（2）惄系列データを MEM（最大エントロピー）法 により䦓波数スペクトル化する.

（3）周波数を255等分し，刘応寸る周波数に刘す る10個のデータの平均バワーを求め, 次式て示され る2水淮のデータを直交表に割り付ける，式の中で、 十符 1 水淮のデータに，一を第2水準のデータとし

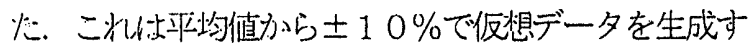
ること垁している。

データ＝平均バワー値 $\times(1 \pm 0 ， 10 ）$

小抏，直交裴山 $\mathrm{L}_{256}\left(2^{255}\right)$ を作成し，用いた。

（4）直交表から得られる仮想データ群を用いて，ユ 一クリッドの基隻空間を作成する. 前述の上うに, こ

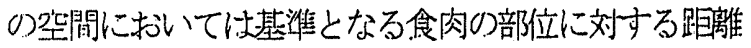
(ニークリッドの距竅) 怙1。0周辺に分布与る。

（5）他の部位の肉に対して上記と同様にして時系列 データ它収集打る。これらのデータに刘して周波数ス ベットラム化し，式（3）によりユークリッドの距離 定求义。.
（6）ユークリッドの距離の大小により食肉および部 位の識別を行う。

Table. 1. Meats used in the experiment

\begin{tabular}{|l|l|l|}
\hline Beef & Pork & Chicken \\
\hline Thigh & Thigh & Thigh \\
\hline Lever & Lever & Lever \\
\hline Chuck roll & Loin & White meat \\
\hline Tongue & Tongue & Breast \\
\hline Tender loin & Tender loin & Gizzard \\
\hline Short plate & Spareribs & \\
\hline Strip loin & Heart & \\
\hline
\end{tabular}

3. 2 実稀結果 牛肉の部位の識別：もも肉を 基準データとした実験結果を図 2 に示寸。もも肉に比 ベてバラ肉, サーロイン，牛タン，牛レバーは距離が 負になっているので軟らかく，ロース，ヒレは距離が 正になっているので硬い：図に示すようにそれぞれの 肉のユークリッドの距離は離九ており，識別が可能で ある。

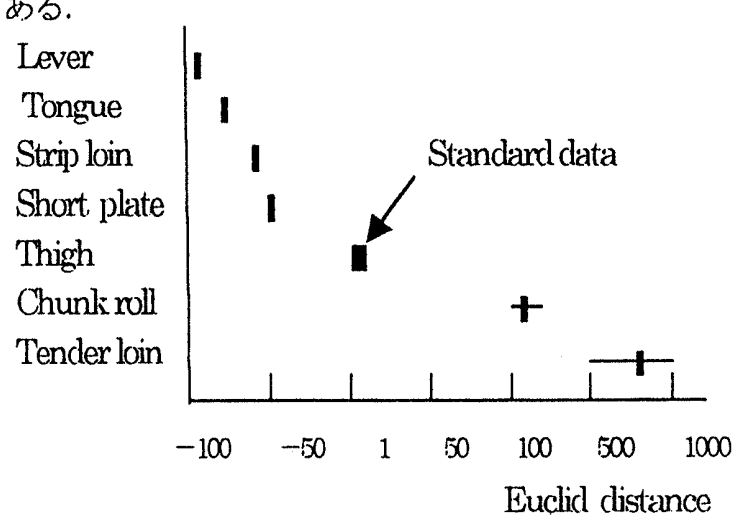

Fig. 2 Discrimination result of beef

\section{5. 結 言}

本研究では，ボールペン䡒に PZT 圧電素子を組み 込んだ蟲覚センサーを用いて食肉の表面をなぞること により得られる時系列データの変化から食肉の硬軟を 測定した．時系列データに MEM 解析を施すことに より得られる周波数スペクトラム値を特徽量として, EED 法を用いることにより食肉の部位の違い，種類 の違いを識別可能であることを示した，本研究におけ

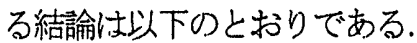

（1）EED 法を基本とした解析により，食肉の種 頪と部位の識別を可能とした，牛肉，豚肉および鷄肉 の3種の肉に対してユークリッドの距離の大小により 識別ダ可能であることを示した。

（2）圧電素子を用いたボールペン型の蟲覚センサ 一を用いて強診することにより，医師の触診に代わる センサーによる触診の可能性を示した。 